\title{
E-EXCHANGE AND THE BOUNDARY BETWEEN HOUSEHOLDS AND ORGANIZATIONS
}

\author{
ASSAR LINDBECK \\ SOLVEIG WIKSTRÖM
}

CESIFO WORKING PAPER NO. 806

CATEGORY 9: INDUSTRIAL ORGANISATION

NOVEMBER 2002

\footnotetext{
An electronic version of the paper may be downloaded

- from the SSRN website: www.SSRN.com

- from the CESifo website: www.CESifo.de
} 


\title{
E-EXCHANGE AND THE BOUNDARY BETWEEN HOUSEHOLDS AND ORGANIZATIONS
}

\begin{abstract}
The new information and communication technology, ICT, induces households to take over tasks from firms and government agencies, using tools and systems provided by these very same organizations. The result is often joint production activities. We argue that the importance of ICT for the exchange process between households and organizations is underestimated by only considering the consequences for the last stage of the process, i.e., the final purchase of goods and services. Our analysis of household behavior utilizes a modified version of Gary Becker's model of the household as a combined producer-consumer.
\end{abstract}

JEL Classification: D1, D2, D8.

Keywords: internet information, e-exchange, household production, coproduction, household power, exit/voice.

Assar Lindbeck

Institute for International Economic Studies

Stockholm University

SE-106 91 Stockholm

Sweden

assar@iies.su.se
Solveig Wikström

School of Business

Stockholm University

SE-106 91 Stockholm

Sweden

sw@fek.su.se

We are indebted to Christina Håkansson for research assistance, and to Astrid Wåke for literature searches on the web. We are also grateful to Evert Gummesson, Erik Kruse, Bo Lennstrand and Hans Rämö for comments on a previous draft, as well as to the participants in the Merit Workshop on ecommerce in Maastricht, November 2001. 


\section{E-exchange and the Boundary between}

\section{Households and Organizations}

\section{Introduction}

The purpose of this paper is to highlight and explore the consequences of the new information and communication technology, ICT, for the division of tasks between households and organizations, and hence for the "boundary" between these two types of agents. An understanding of this issue is vital not only for the sake of knowledge per se, but also for enhancing the ability of organizations and households to exploit potential efficiency gains from ICT and the Internet.

The boundary between households and organizations has always changed. During the industrial revolution, many production tasks were transferred from households to the market, i.e., basically to firms. Important examples are the provision of clothing, semi-prepared food and consumer durables. Obviously, the driving force behind these changing boundaries was technological development (including increased returns to scale) whereby the production efficiency of firms increased relative to that of households for many types of products. Similarly, due to the expansion of the welfare state during the $20^{\text {th }}$ century, other household tasks were taken over by the government, including the responsibility for income security, education and health care. In today's terminology, a vast process of outsourcing of household production has taken place. ${ }^{1}$

However, in connection with the shift to a more pronounced "service economy" during the second half of the $20^{\text {th }}$ century, a development in the opposite direction, "insourcing" from the point of view of the household, has emerged in the case of many commercial products (see e.g. Toffler 1980; 1990; Grönroos 1990; Davidow and Malone 1993; Gummesson 1993; Pine 1993;Wikström et. al. 1994). The driving forces behind this process are quite complex. In line with "Baumol's law" (Baumol, 1967), according to which the

\footnotetext{
${ }^{1}$ Even though a transfer of tasks from households to organizations was a dominating feature during this period it was by no means the whole story. During the first half of the $20^{\text {th }}$ century households took over some tasks performed earlier by firms. Private cars as a substitute for traveling by railroad, and shaving at home instead of going to the barbershop are two examples.
} 
rapid increase in real wages tends to make labor-intensive services more expensive as compared to manufactured goods, households took over the production of some of these services. This development was facilitated by (induced) technological and organizational innovations, such as self-service in supermarkets and restaurants. Unproductive time for households, such as waiting time to be served, was replaced by productive time, when people served themselves, for instance, in stores and restaurants. As a result, the cost increases in the service sector were contained, probably to a very large extent.

Another driving force underlying households' participation in the production process was that higher real income and better education prompted households to become more interested in differentiated and individualized goods and services. Indeed, there is empirical evidence that values nowadays are more individualistic then earlier (Inglehart, 1997). Individuals, therefore, demand more "custom-made" goods and services, which is often facilitated if the household participates in the production process.

The reallocation of tasks from households to public-sector institutions has, however, continued. This is the case both for income insurance and for certain kinds of personal services, in particular for childcare and old age care. Contributing factors are smaller families, the rationalization of household work and probably also changes in preferences among women in favour of labourmarket participation.

The emergence of ICT has also changed the nature of household participation in th-e production process, and extended it to new areas. In fact, with the support of ICT, households now engage in activities that they never conceived of before. To begin with, we analyze this new development in the context of what we call the exchange process between households and organizations. From the household's perspective, this process consists of several different stages. On the bases of her economic resources and preferences, the individual collects information and identifies relevant alternatives. After having compared these alternatives, the individual makes a purchase decision in the market, and the exchange is finalized by payment and delivery of the purchased product. When using the product, the individual in many cases also asks for after-sales services. Similar exchange processes take place in the case of transactions between households and government agencies, although often without any money 
changing hands. The reason why we use the term "exchange process", rather than "purchasing process", is our intention to include both firms and government agencies in the analysis. For the same reason, in the case of electronic exchange, we use the term "e-exchange" (rather than the more usual term e-commerce).

When analyzing the consequences of ICT for the boundary between households and organizations, we simply compare the allocation of tasks among these agents in the exchange and production processes before and after the Internet breakthrough. Our analysis refers to a situation where e-exchange is more advanced than today, and adopted by a vast majority of the population. We believe that this may well occur within less than a decade. One reason is that the Internet has expanded at a very rapid rate in recent years and is expected to continue to do so. In the most advanced countries in terms of Internet use, such as the United States and the Nordic countries, the number of Internet users has increased from 5-10 percent of the population in 1995 to about 50 percent in 2001 (Figure A1 in the Appendix). The rate of expansion is about the same in Japan and the EU, although with a lag of one and three years, respectively, as compared to the most advanced Internet countries. The use of the Internet is also likely to be boosted by wireless connections, in particular via cellular phones. Indeed, as much as 80 percent of the population in some countries now subscribe to such equipment - an increase by about 60 percentage points in just six years (Figure A2 in the Appendix). Moreover, several governments have declared their ambitions to provide their citizens with high-performance broadband networks, with instantaneous and powerful Internet connections at relatively low cost. Such systems will be capable of handling a large assortment of services, which can be reached by almost all citizens in developed countries, including those without previous computer experience (Virtel 2001).

The fact that such systems are available to households and organizations is, of course, not enough. In order to be quantitatively important for e-exchange, information networks also have to be easy to use, which requires a variety of access tools and efficient search processes. Another obvious requirement is that the information content be adequate and the delivery systems efficient. As we know, important improvements are underway in all these respects. ${ }^{2}$

\footnotetext{
${ }^{2}$ On contemporary developments in the United States, see West, 2001a and 2001b; on the Western world
} 
The paper is organized as follows. We begin by introducing our analytical framework for household behavior (section II). Next, in section III, we specify types of information that are particularly relevant for explaining the shifting boundary between households and organizations. In section IV, we consider how ICT induces shifts of tasks from organizations to households. Since this frequently takes the form of co-production, the boundary between households and organizations is often blurred rather than redrawn: the "territory" of joint production of households and organizations expands. We then discuss (section V) how household power is influenced by ICT. Section VI concludes.

\section{Analytical framework}

To do justice to the complexities of the issues dealt with in the paper, we have chosen a non-technical analysis. It is nevertheless important to build the discussion around a strict analytical framework, in which the household is seen not only as a consumer but also as a producer. Our starting point is Gary Becker's (1965) model of household behavior, although we extend and modify the model in some respects.

In this framework, products purchased on the market, denoted by the vector $q$ with the typical element $q_{i}$ (food, visits to restaurants, apartments, books, sporting goods, etc.), are treated as intermediary inputs in household production. The term "market product" then covers both physical goods and services. By way of a household production function, and by the input of labor time, these market products are transformed into final services, denoted by the vector $s$, with the typical element $s_{j}$ (eating, enjoying housing services, intellectual experiences, exercising, etc.). ${ }^{3}$ The set of intermediary products also includes services provided by public-sector authorities. The household production function is written as $s_{j}=F_{j}\left(q, t_{j}\right)$, where $t_{j}$ is time devoted to producing the $j$ th service ( $t_{j}$ is an element of the vector $t$ of time devoted to the production of various types of final services). Final services, rather than the market products, enter the household's preference function, $U(s)$, which is maximized with the household production function, household money income, and available time as constraints. By 
substituting the production function into the utility function, this may alternatively be written as $U=V(q, t)$.

The Becker approach to household behavior is highly parsimonious in the sense that it excludes many real-world aspects of household production and consumption activities. In particular, Becker's model does not consider the possibility that household production itself may have emotional effects on household members in addition to the utility provided by consuming the final services produced. We therefore deviate from Becker by assuming that the household may have direct preferences over the different production tasks themselves.

In this sense, the motives for household production differ from the motives underlying the production activities of firms. For instance, a member of a household may choose to produce specific types of meals not because she is particularly efficient at it, as compared to firms, but rather because she enjoys cooking (a positive utility of specific types of household work), possibly in the company of other family members or friends. Baking a cake that requires hours of work by an inexperienced household member may communicate affection and loyalty within the family. Moreover, members of a household may avoid certain production tasks not because others perform them more efficiently, but simply because they dislike them (high disutility of such tasks). It may thus be reasonable to write the household's direct utility function as $U(s, t)$ rather than $U(s)$. Some elements of the $t$-vector, then, may be interpreted as leisure ("non-work"). We use the Becker framework, with the modifications mentioned above, also to consider emotional aspect of household production.

From the perspective of the Becker model, when tasks shifted from households to firms during the industrialization process, firms started to provide goods which households had formerly produced themselves (such as clothing), i.e., a number of $q$ 's. Over time, completely new types of $q$ 's became available to households, which made it possible for them to produce household services more efficiently themselves. Obvious examples are vacuum cleaners, dishwashers and refrigerators. With the emergence of the Internet, quite different types of $q$ 's have become available, enabling households to perform tasks on their own in new areas, such as handling bank accounts, buying tickets and performing health services at home. Indeed, such adaptation to new tasks by households is a main 
theme of our paper. Before analyzing these developments, it is useful, however, to specify how ICT influences types of information of particular relevance for the division of tasks and hence, for the boundary between households and organization.

\section{Types of information}

In the context of our modified Becker model, we distinguish between four types of information. The first (type 1) is information about available products, including both their attributes (varieties and qualities) and their prices. This type helps households select appropriate inputs $\left(q_{i}\right.$ 's) in production. A second type of information (type 2) may instead be regarded as an intangible input in production. Here, the household uses an information good (i.e., a $q_{i}$ ) to produce utilitycreating services ( $s_{j}$ 's). A third type of information (type 3 ) helps the household combine various inputs in household production; this refers to information about the $F$ ()-function itself, i.e., about blueprints ("how to produce").

The fourth type is related to household-to-household interaction, through which the individual also learns from the experience of other households how to evaluate final services, the $s_{i}$ 's. Knowledge about other individuals' evaluations (preferences) helps develop one's own preferences; hence the individual's $U($ )function may be modified. Preferences are to some extent social phenomena in the sense that they are influenced by social interaction. Such "consumption information" (type 4), and not just "production information", is also important for households. Moreover, as we argue below, an individual's preferences may also change as a result of the household's accumulated experience as a producer or consumer of certain types of services.

Let us illustrate these distinctions. An example of type 1 information is a list of available CD-ROMs and their prices, while the content of a CD-ROM (for example, encyclopedia, mathematics, pictures or music used in the household's production process) is an example of type 2 information. Instructions for using the $\mathrm{CD}$ in combination with other equipment is an example of type 3 information (information about the $F($ )-function), while information about the musicians and understanding music in general, or special types of music, is an example of type 4 information, which enhances the individual's enjoyment of music. 
ICT profoundly intensifies access to all four types of information. The amount of information in various databases is accumulated continuously as an integral part of the interactive process itself (see e.g. Lindbeck and Wikström, 2000). The Internet may be regarded as synonymous with a new information channel, and one of its advantages is that households can choose, in a timeefficient way, from a larger "consideration set" of information sources than before. Individuals can now use the Internet to narrow down a consideration set, so that it becomes manageable for their decision-making capacity. Indeed, in a similar way that Becker's model highlights the household's allocation of time to produce different types of services, models have been designed to analyze how the household allocates time among different media when searching for information (Ratchford, 1982; Hauser et al., 1993). The value of a new information channel then consists of the possibility of allocating time for information search more efficiently than before. The unique value of the Internet from this point of view is that all four types of information mentioned above may be acquired from this channel. This means that many aspects of information search will be shifted to the Internet.

By specifying the type, variety and quality of a product, ICT helps consumers screen available alternatives in order to identify and narrow down a set of suitable options to be viewed in detail (see, e.g., Alba et al., 1997). This is facilitated by the interactive nature of ICT, where customers can ask questions and receive individualized computer-mediated answers supported by artificial search agents (Gatarski, 2001). As compared to telephone communication, the high capacity of ICT enables such individualization, which is economically infeasible by phone because of the labor-intensive nature of telephone communication.

During the period of early enthusiasm for ICT, it was often taken for granted that households would increasingly trade directly with producers, and hence that intermediaries would become less relevant. However, the process of acquiring and interpreting information often turns out to be so complex that households need help from information intermediaries on the Internet. These then correspond to retailers and brokers, such as real-estate and travel agents, in the traditional economy. In fact, information intermediaries that collect and process fragmented bits of information appear to be no less important in the digital economy than in the traditional economy. Virtual communities of individuals, 
news groups and chat groups may also be regarded as new types of information intermediaries.

Intermediaries are also important to guarantee the quality of information in the digital economy. For instance, consumer protection agencies might set up systems (extranets) that protect users and guarantee information quality through "membership," i.e., authorization, user IDs, and passwords. Another type of intermediary is privately run sites that make it easier to evaluate the quality of information by offering structured information about product quality from individual users. Since every provider of information may be identified (name, profession, workplace, etc.), the risk of false identity is reduced. Meanwhile, there is still no radical solution to the problem of fraud (including the deliberate spread of viruses) - and perhaps there never will be. Another well-known problem involves how to arrange for payment of information on the Internet, an issue that we do not pursue here. ${ }^{4}$

Regardless of whether households acquire their information directly from producers, from intermediaries or from other households, systematic comparisons of products require standardized information. Otherwise, appropriate comparisons of alternatives are difficult and hence choice will be of limited value. In several important product areas, particularly concerning health and safety - such as food products, chemicals, vehicles, and certain types of children's products mandatory rules for standardized disclosure of product characteristics are already in place. Mail-order companies have provided such standardized information in their catalogues for a long time. Perhaps this helps explain why such firms have been relatively successful in utilizing the new retail channel provided by ICT. (Another reason is that long ago, such firms developed logistic systems for the delivery of products.) Many large retail firms have also been able to force production companies to provide standardized information about their products, which is considered to be a prerequisite for marketing their product assortment on

\footnotetext{
${ }^{4}$ Information provided so far has usually been free. The costs have been covered mainly by advertisements, i.e., banners. To finance their activities in the future, information providers may have to either start charging for their services or increase the amount of banners. But, financing by banners has its problems. Visitors already complain that flickering banners, which tend to diminish the attractiveness of a Web site, irritate them. In principle, information agents will have to find an optimal combination of a fixed access fee, a variable price per visit, prices for advertisements, and measures that increase the attraction of a Web site for visitors and advertisers. Given that there is no single best solution to this optimization problem, decentralized experimentation is likely to generate different types of solutions for different agents and product groups.
} 
line. In certain products areas, however, the disclosure and standardization of product characteristics have a long way to go.

Improved search helps households identify and obtain more appropriate inputs in their production processes and enhance their efficiency in producing (final) utility-creating services (the $s_{j}$ 's). Well-informed households would also be expected to boost competition (Bakos, 1997). This means that when buying either electronically or via traditional distribution channels households may often, although certainly not always, purchase market products at lower prices. This is a further advantage of ICT for households in addition to greater availability of information.

Since ICT frequently increases search efficiency, it is tempting to assume that products with search attributes will be particularly favored by the ICT revolution, as relevant attributes can then be assessed prior to, or in connection with, a purchase. Obvious examples are homogeneous products and well-known brands. The basic contribution of ICT would then be to provide better information about prices charged by different suppliers. But it has also been argued that the considerable efficiency with which search attributes are communicated electronically may weaken the possibilities of simultaneously communicating information about products with experience and credence attributes electronically, i.e., attributes that can only be evaluated after a product has been used for some time - in the case of credence attributes after quite a long time (Warner, 1993). ${ }^{5}$ When one attribute is convincingly communicated via a specific information channel, the household's attention to other attributes may diminish due to cognitive limitations. Indeed, this hypothesis is supported by empirical experiments (Wright and Lynch Jr., 1995).

However, this problem may not be very serious in the context of the Internet, which also helps households draw on the knowledge of other households regarding how products with experience or credence attributes actually function. Examples are consumer-report sites and product-rating institutes that compare qualities and prices of different brands. Moreover, household-to-household

\footnotetext{
${ }^{5}$ Thus we adhere to the usual distinction between search, experience and credence products (Nelson, 1970; Darby and Karni, 1973), or, perhaps more appropriately, between products with different proportions of search, experience and credence attributes (Wright and Lynch, 1995). In other words, the $q$ 's may be classified not only into physical products and services, and into private and public goods, but also according to the household's ability to assess the quality of products before and after purchase. Note
} 
interaction via the Internet may be particularly useful for drawing on the experience of individuals with similar life situations and experience. Thus, a household would not actually have to buy and use a product with strong experience and credence attributes in order to obtain such information. As a result, it may be attractive to buy some products with these attributes electronically - not only (as before) when the household decides to repurchase a new version of the same product, but also when something is bought for the first time.

These considerations may be particularly important in the case of durable consumer goods, because it may take a long time to find out how well they function, and in the case of services whose quality cannot be judged immediately. Examples of the latter are car or TV repairs, and treatment by dentists or physicians - all examples of services with credence attributes. One of the main reasons why the Internet is likely to have an impact on products with strong experience and credence attributes is that the four types of information proposed above can all be obtained efficiently using this new channel. Such information would otherwise be difficult to obtain without actually buying and using the product. Households would then be less dependent on information provided by producers and suppliers of products, since they acquire comparative information from other, less partisan agents. This may well be one of the key contributions of ICT for households' acquisition of information.

Improved information is not confined to market products supplied by firms. ICT is also becoming increasingly important for services provided by the public sector. The availability of information on the Internet from local governments, state governments and federal authorities in the United States has recently undergone rapid expansion (West 2001a, 2001b). Several European governments have also started to use the Internet as a means of providing more and better structured information to citizens about the public sector. The volume of information is already huge, but so far interactivity is usually quite limited. In cases were interactivity exists, it usually refers to simple questions and answers. Still, such information on the Internet may be quite valuable because it is very expensive for public-sector agencies to provide via alternative sources and may otherwise not be easily available. Obvious examples are information from, and 
about, administrative agencies (such as regulatory authorities), government agencies in charge of transfer payments (including social insurance) and publicsector institutions that provide social services of different types (education, health care, child care, old-age care, etc.) - all of which are examples of type 1 information according to our classification. A concrete example is that ICT makes it easier for parents and students to find suitable education after comparing the characteristics and achievements of different schools.

Via the Internet, individuals may also be able to apply for permits of various types from public authorities, such as building permits - an example of type 2 information supplied by public-sector agencies. Another example is the increased possibility for individuals to file their income-tax assessment on the Internet. Education via the Internet is another important example of the provision of an information good by the public sector. Type 3 information, related to the public sector, may be exemplified by patients obtaining the latest findings about relevant medical care and the treatment of specific diseases (PriceWaterhouseCoopers, 1999; Gustafson, 2000). Through fora for direct household-to-household interaction, people also have access to the experience of other, more experienced patients with the same disease (Margherio et al., 1999). As a consequence, she may gradually learn to handle her disease by revising her priorities, hence experiencing a change in her own preferences - an example of the endogenous nature of type 4 information in connection with co-production.

Not only will it become easier for households to obtain information about goods and services; providers may also find out more about the needs, preferences and resources of individuals and groups of individuals, thereby enhancing their ability to supply adequate services. This information may be considerably amplified by new interactive devices such as picture phones and web cameras, whereby individuals can concretize their needs and problems, for instance regarding health conditions subject to home treatment as a substitute for hospital care. ICT also provides organizations with new tools that increase their ability to adjust production in a flexible way to changes in individual taste and demand (Milgrom and Roberts, 1990). Hence, ICT offers organizations more production flexibility in response to shifts in household demand.

Generally speaking, society at large is likely to gain as firms accumulate information about individuals' preferences in their databases. This could well 
result in a potential Pareto improvement in the allocation of resources. There are two serious problems in this context, however. One is that individuals may experience a loss of privacy when information about their habits and preferences is disseminated via the Internet. A second problem is that a single firm may obtain a monopoly on information concerning a particular person. The individual may then be "locked-in" to this firm, and hence be charged a monopoly price. This would raise producers' surplus rather than consumers' surplus, reflecting a rise in the market power of firms rather than households. A way of mitigating this problem would be a more competitive environment, in which more than one firm has this type of information about an individual, and would hence be able to offer individually customized products.

A further complication is related to peoples' cognitive limitations when maneuvering in a virtual context. Both experience and systematic research point to fundamental difficulties in overcoming cognitive limitations when moving from a physical to a virtual context. ${ }^{6}$ Moreover, people with little education seem to require simple navigation technology in order to operate on the Internet (Gustafson, 2000). It is still not clear how this problem could best be solved. One promising avenue may be to rely on an interface with strong real-world and local attachment, where the user's screen is provided with a local map where facilities (stores, institutions, etc.) are easily recognized through names and pictures in a realistic setting (Wikström et. al., 2001). Maneuvering within these facilities could take the form of interaction with human-like robots. Indeed, some research indicates that individuals feel more comfortable interacting with human replicas, with which they may exchange information simultaneously, than interacting via text (Ginsburg, 2001).

These tendencies indicate that the ability of an individual to learn to maneuver in a virtual context may often be improved by support both from human replicas in the form of voice and images, and from traditional real-world facilities. It also suggests that the proportions between virtual and real-world elements will not develop monotonically; instead, a process of "two steps forward-one step backward" often characterizes the march into the virtual world. Indeed, the

\footnotetext{
${ }^{6}$ See, for instance, Carlell (2001), Frostling-Henningsson (2000), Lennstrand (2001) and Wikström (2002).
} 
general lesson is that new ICT systems, to be successful, have to be adapted to individuals' cognitive capacity, rather than vice versa.

\section{Changes in the division of tasks}

Whenever technology changes, reallocation of tasks is largely driven by potential efficiency gains. In the case of ITC, efficiency gains are achieved not only as tasks are shifted, but also to a large extent by increased co-production between households and organizations. One question then is whether such developments are seriously constrained by the limited time available to households where, today, both spouses usually work in the labor market. Another question is whether the efficiency gains from ICT are constrained by the fact that the final stage of the purchases continues to be conducted via traditional channels.

\section{IV:1. Four types of efficiency gains}

In terms of our household production function, $s_{j}=F_{j}\left(q, t_{j}\right)$, the shifting of tasks to households for efficiency reasons may be initiated in four different ways. Thanks to ICT, households may (i) identify a more appropriate input, i.e., a better $q_{i}$; (ii) find a lower price of an input; (iii) acquire a more efficient production technology, i.e., a better $F($ )-function; or (iv) save time, $t$, or alternatively be able to use "cheaper" time in its production process. If various combinations of such changes result in lower total costs for the household (pecuniary costs plus time costs) for certain tasks, as compared to the costs of purchasing final services on the market, the household has an incentive to take over such tasks from other agents.

More specifically, when ICT opens up access to intermediary products with appropriate attributes (better quality of some $q_{i}$ 's), or with a lower price, households are induced to take over the production of final services intensively using such products as inputs in household production. ${ }^{7}$ ICT may also change the composition of household consumption in favor of services that become less expensive for the household to produce. For instance, owing to new possibilities

\footnotetext{
${ }^{7}$ The increase in the input of a specific market product in household production will be larger, the greater is the elasticity of substitution in production relative to other market products, and the greater is the elasticity of substitution in consumption between this specific final service and other services.
} 
of downloading music from the Internet, the price of consuming music falls, and the household is encouraged to consume more music. ${ }^{8}$

Improvements in households' production technology, reflected in shifts in the $F($ )-function, often require not only new general ICT, manifested by the PC and the Internet, but also specific tools and systems provided by various firms. Moreover, special support functions are frequently incorporated into products or services through ICT. For instance, someone who is under medical treatment for hypertension may automatically be reminded on his screen when to check his blood pressure. Or, when products malfunction, users may automatically be told what is wrong, what to do about it, what spare parts are needed, where they can be ordered, how they should be inserted, etc. More generally, households may be relieved of certain tasks either when monitoring functions are built into products, or when automatic online connections between the product and service suppliers are available. In this way, household members may be relieved of some anxieties and/or the pursuit of trivial tasks. Suppliers then take responsibility for parts of the household's production process. This also encourages product development in firms.

In order to take on new tasks, the household may also need assistance from competent personnel. Firms and organizations could then provide intermediary products and help households develop new and more efficient $F($ )functions. One example is that some firms engaged in electronic trade, such as mail-order companies, could establish bricks-and-mortar stores as complements to their Internet transactions. Another example is Internet banking, which is difficult to set up without implementing support systems from real-world banks, bank personnel, and telephone service (Gerdes and Rolland, 2000). Firms sometimes speed up the process by which households take over tasks, by charging high prices for traditional services. An important example is high and rapidly rising prices for bank services provided at bank premises so as to induce households to take over tasks via Internet banking.

Our reason for writing the household utility function $U(s, t)$ rather than $U(s)$ was that households may also have emotional attitudes to different

\footnotetext{
${ }^{8}$ The demand for a market good for which productivity has increased will rise (fall) if the combined effect of substitution in production and consumption and of the income effects are stronger (weaker) than the productivity change itself (which reduces the input necessary to produce a given output of services).
} 
production tasks. In the case of the Internet, fragmented empirical evidence indicates that some individuals simply enjoy this new information channel, and are in fact stimulated by using the new technology. Some individuals also experience a sense of empowerment when they discover what they can do via the Internet (Wikström, 2002). So far, we have very little systematic empirical knowledge about the importance of such attitudes in connection with e-exchange. Some examples mentioned in the literature include transactions in financial markets. Not only have they become less expensive as compared to traditional methods, but individuals may also find it exciting to follow share prices on the Internet and carry out the transactions themselves (Carlell, 2001). Moreover, people who dislike shopping in traditional stores may feel relieved by shifting to e-commerce. Some families have started to buy groceries on the Internet not only to save time and/or money, but (also) because they dislike visiting crowded supermarkets (Frostling-Henningsson, 2000).

More generally, households would be expected to take over tasks from firms either for narrow "economic" reasons in order to reduce total costs or for subjective reasons in connection with household production.

\section{IV: 2 Joint territories}

As we have seen, reallocation mechanisms are usually a result of joint efforts of households and organizations. As a consequence, organizations increasingly regard households not just as receivers of goods and services, but also as co-producers. Indeed, the interactive nature of ICT implies that households can take an active part in the production process, and thereby influence production according to their own preferences.

As households and organizations increasingly cooperate in production, $a$ new territory of joint production is established rather than change in the borderline between households and organizations. In this new territory, households provide labor (which is increasingly expensive), while firms provide ICT-based systems and different types of tools (capital). Indeed, this is one of the main assertions of our paper. Such extended offers by firms may enable both households and firms to perform tasks that neither of them had previously been able to accomplish on their own (Normann, 2001). This, in fact, is the essence of the so-called "enabling strategy" of organizations, a strategy strongly facilitated 
by ICT. Tasks that households take over from organizations, thanks to ICT, may be regarded as substitutes for tasks previously pursued by firms. But at the same time, the systems and tools provided by firms are often complements to the new tasks performed by households. In terms of our earlier classification of types of information improved by ICT, co-production is particularly favored by better information about new $q$ 's, i.e., new inputs in household production, and about the $F()$-function, i.e., how household services should be produced. A special form of co-production arises when households demand specific products adjusted to their individualized preferences. Households may then specify desired product characteristics, which is the essence of mass customization.

\section{IV:3 Do households have enough time?}

But do households really have time to take over new production tasks? One answer is that when households take over additional tasks this does not necessarily put more pressure on the household's time budget. On the contrary, households often take over tasks with the aid of ICT in order to save time. For instance, households are often relieved of having to physically visit the service provider. Moreover, they may be able to use relatively "inexpensive" time, i.e., time with low opportunity costs (Frostling-Henningsson, 2000; Carlell, 2001). Obvious examples of the latter are information gathering or transactions on the Internet in the evening or on weekends. Households are particularly likely to use ICT in a timesaving way when two adults in the household work outside the home.

ICT may also help the household save time by avoiding mistakes, since less time and energy would then have to be devoted to complaints and waiting for the repairs of purchased products. Experimental research indicates that busy households are particularly inclined to acquire so-called "negative" information, i.e., information about defective products (Kanouse and Hanson, 1972; Wright, 1974; Svensson and Edlund, 1987). Such information may be facilitated by the Internet, both on commercial sites and via household-to-household interaction.

\section{IV:4 Illustrations}

There are many well-known examples of tasks which households take over from firms. For instance, when the individual makes financial transactions 
electronically - such as the payment of bills, bank deposits, repayment of loans, and management of financial assets - she participates actively in the production of her own financial services. ${ }^{9}$ In Sweden, Internet payments at two major Swedish banks increased from 10 percent in 1998 to 45 percent in $2002 .{ }^{10}$ Electronic transactions have also developed rapidly in the insurance sector, where households have partly taken over the retailing activities previously pursued by insurance brokers and salesmen (middlemen). Buying tickets or booking hotel accommodation is other well-known areas where households have taken over activities from firms. Online ticket sales have few organizational constraints, perhaps because computer reservation systems have been in place for years. As a result, households have integrated retailing into their production activities.

Examples also abound where ICT facilitates mass-customization such as for cars, kitchens, CDs, cosmetics, various types of financial services and leisure travel. ${ }^{11}$ This issue may also be exemplified by leisure travel. There is a tendency today to shift from package tours to more individualized travel packages.

Supported by the Internet, an individual may decide the components of her tour in terms of destination, transport mode, accommodation, special events, activities, etc. In this way, she can "customize" her leisure travel in accordance with her own preferences, instead of buying a standardized travel package. The background is not only the general trend among individuals to choose more differentiated packages, but also the fact that ICT has drastically reduced the costs of composing individualized travel packages.

Another example where households have already started to take on new tasks is the rapidly expanding system of self-care, to some extent replacing hospital care. The exchange of pictures on the Internet between patients and the health-care providers is likely to become particularly important. Such interaction has also turned out to be beneficial in analyzing data, monitoring performance and

\footnotetext{
${ }^{9}$ This is reflected in extremely low operating costs - less than one cent to conduct a transaction on the Internet as compared to more than a dollar if handled by a bank teller (Booz-Allen and Hamilton, 1999, and Reddman, 1997). In a long-term perspective, negligible operating costs are likely to lower the prices of financial services. Since the fixed costs are quite high, banks also tend to charge fees for their Internet services. Most customers have to accept this because of limited competition due to switching costs for households when changing bank, and in some countries because of a highly oligopolistic banking structure.

${ }^{10}$ Information from SE-bank and Svenska Handelsbanken.

${ }^{11}$ See, for instance, Grönroos (1990), Gummesson (1993), Davidow and Malone (1993), Pine (1993) and Wikström (1996).
} 
transmitting reminders to patients (Gustafson, 2000; Boston Consulting Group, 2001). For instance, Internet connections to glucose monitors, peak flow meters to measure lung capacity, or scales to monitor weight permit health providers to collect and automatically transmit daily or weakly readings from patients with diabetes, lung disease, or heart problems. Physicians can use the results to decide when and what type of intervention may be necessary (Boston Consulting Group, 2001). In several cases, patients learn to participate in their own treatment at home by using equipment provided by a hospital. An example is a dialyses machine combined with o-line information.

As a result, more therapies are taking place in patients' homes with the support of ICT (Bezold, 1998). Asthma and diabetes patients, for example, are becoming co-producers of their own treatments. Interaction between patients and health-care providers has also begun to improve the quality of life of cancer patients, help people stop smoking and lose weight, etc. Individuals may also check their own health status, register the effects of different treatments and participate in deciding their medication, while experts at the hospital provide monitoring and counseling online. Moreover, once a patient understands the details of her care, she finds it easier to choose among alternative types of treatment and providers. This is an example of a service with strong credence attributes where the household gains information not only through the Internet, but also via the individual's participation in the production process.

On the basis of improved information, a patient may even suggest methods and medical treatments other than those offered by her physician. This is an important factor, because asymmetric information between physicians and patients about possible treatments has traditionally been regarded as a particularly serious obstacle to the development of well-functioning markets for health and medical services.

Another area where households may participate in service production is "adventures" in exotic environments, possibly using virtual-reality equipment as a complement to, and in some cases even a substitute for, physical traveling. ${ }^{12}$ Households have also started to take on production tasks in areas related to personal safety - an area in which innovative applications of ICT are becoming

\footnotetext{
${ }^{12}$ See interesting speculation on these issues by Pearson (1999).
} 
increasingly available. New electronic devices will make it easier for homeowners to safeguard against trespassing and crime, possibly with the help of equipment and services (such as alarm systems) provided by private firms or public-sector authorities (police). Parents may be better able to monitor small children (such as locating them at any given time).

\section{$I V: 5$ The role of ICT for different stages of the exchanges process}

Clearly, the Internet is used more extensively in the early stages of the exchange process than in the final stage, i.e., when a transaction is completed by payment and delivery. It should be noted, however, that the efficiency gains of eexchange are not limited to situations where a final purchase is closed on the Internet. Large efficiency gains are often achieved already in the process of information search on the Internet. Even if the final stages are conducted in traditional ways, fundamental changes occur in the content of these stages. The information and search process on the Internet makes the individual more knowledgeable, self-confident and competent when making a purchase decision. Hence, the importance of the Internet for the exchange process is underestimated if we only consider its direct role for the final stages of the process.

The importance of ICT for different stages of the exchange process will, of course, differ among products. In the case of information goods, the entire exchange process may in principle be conducted on the Internet. In reality, however, many individuals who collect information via the Internet still seem to prefer completing the final stages of a transaction in traditional ways. There are many reasons for this. Additional information may be required; a visit to a traditional store may enhance trust and security about payment and delivery. Indeed, even in the case of information goods, individuals often prefer to close a transaction in traditional ways. One example is the purchase of leisure tours. In Sweden 10 percent of such purchases have recently taken place on the Internet, but only one visit out of 100 to a website results in a purchase in this area ${ }^{13}$. In the case of other goods, such as the purchase of real estate, the final stage cannot be conducted in this way simply because of legal requirements for such purchases,

\footnotetext{
${ }^{13}$ Statistics from the organization May Travel, based on the activities of travel agents covering the bulk of the Swedish market.
} 
although considerable information may be acquired via the Internet. In the case of purchases of tangible consumer goods, where delivery obviously cannot take place on the Internet, a multitude of organizations of delivery firms have emerged. Sometimes the household may pick up the product and on other occasions let firms be responsible for both assembly and final delivery. In the latter case, the household, in fact, outsources activities, which it used to perform itself.

Referring to our classification of types of information relevant for ICT, it is clear that types 1 and 2 information about available inputs, including information goods, are highly pertinent to the exchange process, while in the case of household production, including co-production, all four types are important.

\section{The consequences for exit and voice}

We have argued that ICT may induce households to take over tasks from organizations when people acquire the information required to identify suitable inputs, $q$ 's, in their production process. This aspect may be examined in terms of Hirshman's (1960) distinction between exit and voice mechanisms. In principle, a household may acquire more appropriate $q$ 's because of either improved exit, in the sense of greater opportunities to choose among available brands and sellers, or stronger voice in the sense of improved ability to communicate with suppliers about its opinions regarding existing or desired products. In both cases, ICT tends to boost household power.

Improvements in the exit option are particularly obvious in the case of privately supplied products since there are often alternatives and hence competition. Circumstances are different in the public sector, where many services are provided under monopoly-like conditions, although ongoing privatization and deregulation tend to make the situation more competitive.

As for the voice option, households may express their views not only directly on firms' sites but also indirectly via virtual communities and chat groups which are independent of suppliers. Since these groups coordinate the voices of many individuals, firms are forced to listen simply to keep their customers. A good example is the Swedish site, CINT (www.cint.se), mentioned earlier, where individuals may obtain information about how others evaluate products and services, in detail and in several different dimensions. First, the site provides 
aggregate information about various features of a product as judged by households. Second, it offers rather detailed information on how specific individuals (identified by their first name) evaluate a product. An individual may also communicate directly on the net with others who offer information about a product.

In the case of public-sector services, the voice mechanism, and not just the exit mechanism, is usually weak. In this sector, voice is largely exerted via the ballot box, where voters are asked to choose among a few large packages of policy measures. The situation will begin to change, however, as many individuals simultaneously express their views about a particular government institution on the Internet. Since such information is highly visible to everyone, responsible politicians and administrators will not be able to neglect these views. In the public sector opportunities are quite limited so that a stronger voice option via ICT is particularly important. In fact, improved systems for expressing and exchanging views on the Internet between individuals and public-sector agents are in the pipeline in several countries. ${ }^{14}$

To summarize: ICT boosts the power of households in the private sector in terms of both exit and voice. Empirical studies by Brynjolfsson and Hitt (1994) suggest that ICT has often resulted in a rise in consumers' surplus relative to producers' surplus, which may be interpreted as increased market power of households. ICT could result in similar enhancement of the power of households in the public sector, at least if entry and competition are encouraged. Exit and voice are highly complementary mechanisms not only in the private but also in the public sector. This complementarity is likely to increase as a result of increased freedom of choice via privatization and voucher systems, and hence improved exit opportunities in the public service sector.

Firms cannot afford to be passive when household market power increases owing to better and more accessible information and stronger voice opportunities. Instead, they would be expected to counter by taking advantage of the economic gains from more efficient information systems. Obvious examples are measures designed to differentiate the products offered. Firms might also "lock-in"

\footnotetext{
${ }^{14}$ In Sweden, such possibilities are under study by the organization of regional governments (Norberg, 2002). Special search engines for public-sector services are also likely to emerge (Price Waterhouse Coopers, 1999).
} 
households after acquiring better information than others about the preferences of individual households. Moreover, firms have incentives to make it more difficult to compare prices and product attributes, for instance, by artificial product differentiation and complex price structures (Bakos, 1997). Indeed, recently privatized and deregulated firms in industries such as banking, telecommunications and electricity are highly creative in designing obstacles to households' comparison of alternatives.

\section{Concluding Remarks}

ICT, including the Internet, still has rather limited effects on the number and value of transactions completed on-line (final purchase, payment and delivery). ICT has, however, far-reaching impact on the early stages of the exchange process, i.e., on information search and the evaluation of alternatives. This means that ICT also has indirect consequences for the content of the final stages of the exchange process, regardless of whether these stages take place over the Internet or in traditional ways. Thus, if looking only at the number (or value) of final purchases conducted via the Internet, the importance of ICT for the exchange process as a whole, including its final stages, is underestimated. This point is also important in the case of services provided by the public sector. Although on-line information search is usually not interactive in the public sector, at least not yet, it is valuable to households since it would be very costly to supply the same volume of information by traditional methods (such as phone calls), which are quite labour intensive.

ICT also tends to strengthen household "voice" in relation to organizations of different types. When the opinions of individuals are highly visible on the Internet, in particular in aggregate form, firms and government agencies have much to lose by neglecting these opinions. Organizations, therefore, have to become more concerned about their reputation, particularly in handling consumer complaints and dealing with ethical issues.

Whenever ICT changes the relative efficiency of household production, the allocation of tasks between households and organizations is influenced. Earlier tendencies toward joint production activities are also enhanced. In this connection, organizations often provide tools and systems that facilitate household service 
production. Thus, while organizations supply capital and technology, households provide labour. This development also facilitates household consumption of labour-intensive services, which tend to become increasingly expensive to buy for reasons explained by Baumol's law.

These new possibilities for joint production open up important business opportunities for firms. New profitable markets emerge when firms provide new tools for households' own production of services, which households then can acquire more efficiently than earlier. The reason is that joint production with the help of ICT-related tools imply important benefits for households in the form of increased possibilities for households to get individualized services in a costs and time efficient way. The ability of firms to exploit these new opportunities depend on their ability to develop appropriate tools for such joint production.

ICT has also important consequences for the allocation of tasks between households and government agencies. In particular, joint production between households and government agencies by the help of the new information technology provides opportunities to deal with the costs explosion in the highly labour intensive government production of services. Health care is perhaps the most important area where such opportunities exist. Such care in the home is increasingly becoming feasible by the help of tools and on-line interactive communication facilities provided by health-care institutions. Indeed, there is already considerable experimentation in this field.

Even though the main driving force behind ICT-induced shifts of tasks between households and organizations is changes in relative efficiency in production, these shifts also depend on other factors. In particular, households' choice of tasks is influenced by emotional factors. We have argued that ICT makes it easier for households to choose production activities that they like, and to avoid activities that they dislike. Again, health care is an important example, since individuals may get emotional benefits from staying in their home during their medical treatment, rather than being hospitalised.

We have concretized our points with examples from such diverse areas as financial services, entertainment and other leisure activities, durable consumer goods and health care. Each case may seem rather trivial in isolation. But the sum of many small changes in the allocation of tasks between households and organizations over time may have major consequences for the boundary between 
these agents, and for the "joint territory" of the production activities of these agents - and hence also for the lives of individuals.

\section{References}

Alba, J., Lynch, J., Weitz, B., Janiszewski. C., Lutz, R., Sawyer, A. and Wood, S., 1997, "Interactive Home Shopping: Consumer, Retailer, and Manufacturer Incentives to Participate in Electronic Marketplaces”, Journal of Marketing, 61, pp. 38-53.

Bakos, Y.S., 1997, "Reducing Buyer Search Costs: Implications for Electronic Marketplaces", Management Science, 43(2), pp.1676-92.

Baumol, W., 1967, "Macroeconomics of Unbalanced Growth: The Anatomy of Urban Crisis", American Economic Review 57, June, pp. 415-426.

Becker, G., 1965, “A Theory of the Allocation of Time”, Economic Journal, LXXV(299), pp. 493-517.

Bezold, C., 1998, “Tools for Better Decision-making”, in C. Bezold, J. Frenk and S. McCarthy (eds.), Prospects for Achieving Health for All, Alexandria, VA: Institute for Alternative Futures.

BCG, Boston Consulting Group Focus, 2001, "Vital Signs Update: Doctors say Ehealth Delivers", September.

Booz-Allen and Hamilton, 1999, "Internet Banking: A Survey of Current and Future Development”, in Margherio, L., Henry, D., Cooke, S. and Montes, S., 1999, The Emerging Digital Economy, Secretariat on Electronic Commerce, Washington DC: US Department of Commerce.

Brynjolfsson, E. and Hitt, L., 1994, “Creating Value and Destroying Profits?”, http://ccs.mit.edu/CCSWP183.html.

Carlell, C., 2001, “Technology in Everyday Life. A Study of Consumers and Technology in a Banking Context”, School of Business Reports no. 2001:2, Stockholm University.

CINT, http://www.Cint.se.

Darby, M. and Karni, E., 1973, "Free Competition and the Optimal Amount of Fraud", Journal of Law and Economics, 16, pp.66-86.

Davidow, W. H. and Malone, M. S., 1993, The Virtual Corporation, New York: Harper Business. 
Frostling-Henningsson, M., 2000, Daglighandeln över nätet ... vad innebär det?

(Everyday Purchases on the Net - What Does it Imply?), Thesis, School of Business, Stockholm University.

Gatarski, R., 2001, Artificial Market Actors, Thesis, School of Business, Stockholm University.

Gerdes, J. and Rolland, E., 2000, WWW: What went Wrong. An Analysis of the Dot. Coms. Proceedings of the Third International Conference on Telecommunications and Electronic Commerce (ICTC), South Methodist University, Dallas, TX.

Ginsburg, M., 2001, "Volunteerism, Social Capital, and Online Communities", paper presented at the Infonomics/Merit Workshop on Digitisation of Commerce: e-Intermediation, Maastricht, Nov. 23-24.

Grönroos, C., 1990, Service Management and Marketing. Managing the Moments of Truth in Service Competition. Toronto: Lexington Books.

Gummesson, E., 1993, Quality Control in the Service Sector. CTF, Karlstad University.

Gustafson, D., 2000, Interactive Health Communications for Diverse Populations, Draft, Department of Industrial Engineering and Preventive Medicine, University of Wisconsin-Madison.

Hauser, J.L., Urban, G. and Weinberg, B., 1993, "How Consumers Allocate Their Time When Searching for Information", Journal of Marketing Research, XXX(4), pp. 452-466.

Hirshman, A., 1960, Exit, Voice, and Loyalty, Cambridge, MA: Harvard University Press.

Inglehart, R., 1997, Modernization and Postmodernization, Princeton: Princeton University Press.

Kanouse, D., and Hanson Jr., R., 1972, “Negativity in Evaluations”, in E.E. Jones (ed.) Attribution: Perceiving the Causes of Behavior, New York: General Learning Press, pp. 27-46.

Lennstrand, B., 2001, "Hype it. How You Perceive Evolution in Technology", School of Business Research Report 2001:8, Stockholm University. Lindbeck, A. and Wikström, S., 2000, "The ICT Revolution in Consumer Product Markets", Consumption Markets and Culture, 4, pp. 1-23. 
Margherio, L., Henry, D., Cooke, S. and Montes, S., 1999, The Emerging Digital Economy, Secretariat on Electronic Commerce, Washington DC: US Department of Commerce.

Milgrom, P. and Roberts, J., 1990, The Economics of Modern Manufacturing Technology, Strategy and Organization, American Economic Review, 80, pp. 511-528.

Nelson, P, 1970, “Information and Consumer Behavior", Journal of Political Economy, 78:2, pp. 311-329.

Norberg, L., 2002, @llavinner-e-relationer öppnar världen (Everyone Wins - Erelations Open New Worlds), mimeo.

Normann, R., 2001, Reframing Business. When the Map Changes the Landscape, Chichester: Wiley.

Pearson, I., 1999, Our View of the Future, /http://innovate.bt.com/viewpoints/ pearson/brands.htm.

Pine, B.J. II, 1993, Mass Customization. New Frontiers in Business Competition, Cambridge, MA: Harvard Business School Press.

Price Waterhouse Coopers, 1999, Health Cast 2010. Smaller World, Bigger Expectations, www.pwcglobal.com/healthcare.

Ratchford, B., 1982. "Cost-Benefit Models for Explaining Consumer Choice”, Management Science, 28, pp. 197-211.

Reddman, R., 1997, "Sweeping the Appeal of ATMs". Bank System \& Technology, November, p. 38.

Svensson, O. and Edlund, A., 1987, "Change of Preferences under Time Pressure: Choice and Judgments", Scandinavian Journal of Psychology, 28, pp. 322330.

Toffler, A., 1980, The Third Wave, London, Pan Books.

Virtel, M., 2001, "Fast Internet - So What?" Connectis, 11, Supplement to the Financial Times, May, pp. 10 - 18.

Warner, J., 1993, "Commentary: Home Shopping Has to Beat the Siren Song of the Store", Business Week, July 26, p. 60.

West, D. M., 2001a, Urban E-Government: An Assessment of City Government Websites, www.brown.edu/Departments/Taubman_Center/polreports/ egovt01city.html 
West, D. M., 2001b, State and Federal E-Government in the United States, 2001, www.brown.edu/Departments/Taubman_Center/polreports/egovt01city.html

Wikström, S., 1996, “The Customer as Co-Producer”, European Journal of Marketing, 30(4), pp. 6-19.

Wikström, S., 2002, “Consumer's E-buying Revisited”, Research Report no. 2002:11, School of Business, Stockholm University.

Wikström, S., Normann, R., Anell, B., Ekvall, G., Forslin, J. and Skärvad, P.H., 1994, Knowledge and Value, A New Perspective on Corporate Transformation, London and New York: Routledge.

Wikström, S., Lennstrand, B. and Persson, C., 2001, “e-solutions - Design Principles for Ease-of-Use”, in B. Stanford-Smith and E. Chiozza (eds.), Practices for a Global Networked Economy, Amsterdam: IOS Press, pp. 375-381.

Wright, P., 1974, “The Harassed Decision Maker: Time Pressure, Distraction and the Use of Evidence", Journal of Applied Psychology, 59(5), pp. 555-561.

Wright, A. and J. Lynch Jr., 1995, “Communication Effects of Advertising versus Direct Experience when Both Search and Experience Attributes are Present", Journal of Consumer Research, 21, March, pp. 708-718 


\section{Appendix}

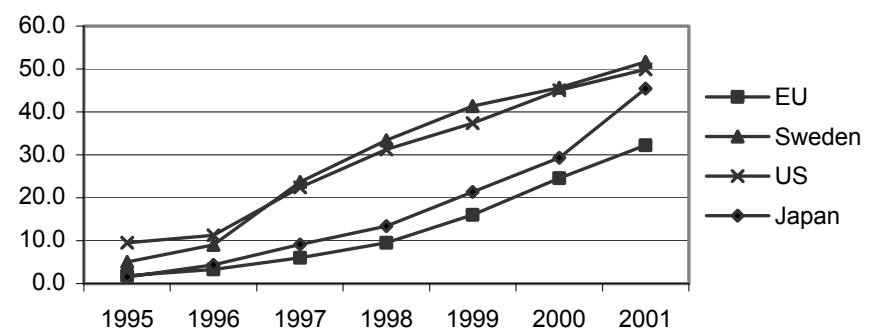

Source: ITU World Communication indicators 2002

Figure 1: Internet users (estimated) per 100 inhabitants

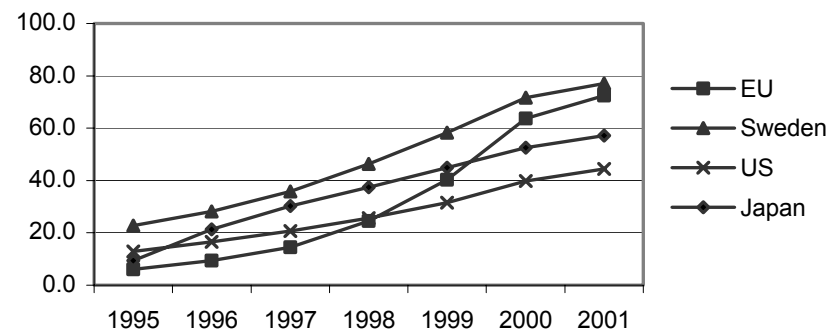

Source: ITU, World Telecommunication indicators 2002

Figur 2: Cellular mobile telephone subscribers per 100 inhabitants

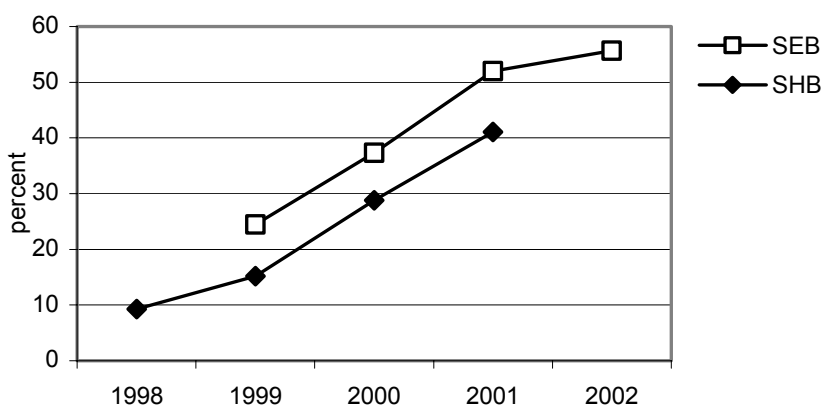

Source: $S H B, S E B$

Figur 3: Share of internet payments, two major swedish banks

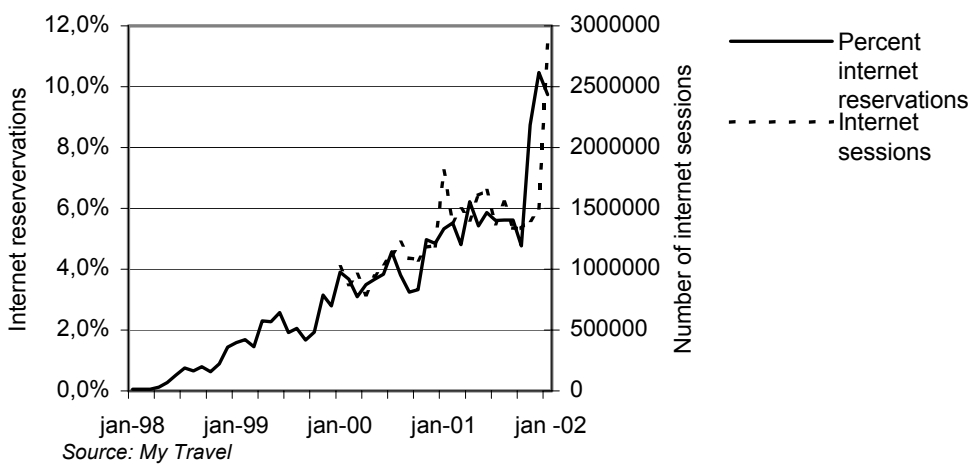

Figur 4: Share of travel reservations made on the Internet $\%$, number of internet sessions, total web My travel 


\section{CESifo Working Paper Series}

(for full list see www.cesifo.de)

739 Robert J. Gary-Bobo and Sophie Larribeau, A Structural Econometric Model of Price Discrimination in the Mortgage Lending Industry, June 2002

740 Laurent Linnemer, When Backward Integration by a Dominant Firm Improves Welfare, June 2002

741 Gebhard Kirchgässner and Friedrich Schneider, On the Political Economy of Environmental Policy, June 2002

742 Christian Keuschnigg and Soren Bo Nielsen, Start-ups, Venture Capitalits, and the Capital Gains Tax, June 2002

743 Robert Fenge, Silke Uebelmesser, and Martin Werding, Second-best Properties of Implicit Social Security Taxes: Theory and Evidence, June 2002

744 Wendell Fleming and Jerome Stein, Stochastic Optimal Control, International Finance and Debt, June 2002

745 Gene M. Grossman, The Distribution of Talent and the Pattern and Consequences of International Trade, June 2002

746 Oleksiy Ivaschenko, Growth and Inequality: Evidence from Transitional Economies, June 2002

747 Burkhard Heer, Should Unemployment Benefits be Related to Previous Earnings?, July 2002

748 Bas van Aarle, Giovanni Di Bartolomeo, Jacob Engwerda, and Joseph Plasmans, Staying Together or Breaking Apart: Policy-makers' Endogenous Coalitions Formation in the European Economic and Monetary Union, July 2002

749 Hans Gersbach, Democratic Mechanisms: Double Majority Rules and Flexible Agenda Costs, July 2002

750 Bruno S. Frey and Stephan Meier, Pro-Social Behavior, Reciprocity or Both?, July 2002

751 Jonas Agell and Helge Bennmarker, Wage Policy and Endogenous Wage Rigidity: A Representative View From the Inside, July 2002

752 Edward Castronova, On Virtual Economies, July 2002

753 Rebecca M. Blank, U.S. Welfare Reform: What's Relevant for Europe?, July 2002

754 Ruslan Lukach and Joseph Plasmans, Measuring Knowledge Spillovers Using Patent Citations: Evidence from the Belgian Firm's Data, July 2002 
755 Aaron Tornell and Frank Westermann, Boom-Bust Cycles in Middle Income Countries: Facts and Explanation, July 2002

756 Jan K. Brueckner, Internalization of Airport Congestion: A Network Analysis, July 2002

757 Lawrence M. Kahn, The Impact of Wage-Setting Institutions on the Incidence of Public Employment in the OECD: 1960-98, July 2002

758 Sijbren Cnossen, Tax Policy in the European Union, August 2002

759 Chandima Mendis, External Shocks and Banking Crises in Developing Countries: Does the Exchange Rate Regime Matter?, August 2002

760 Bruno S. Frey and Lars P. Feld, Deterrence and Morale in Taxation: An Empirical Analysis, August 2002

761 Lars Calmfors and Åsa Johansson, Nominal Wage Flexibility, Wage Indexation and Monetary Union, August 2002

762 Alexander R. W. Robson and Stergios Skaperdas, Costly Enforcement of Property Rights and the Coase Theorem, August 2002

763 Horst Raff, Preferential Trade Agreements and Tax Competition for Foreign Direct Investment, August 2002

764 Alex Cukierman and V. Anton Muscatelli, Do Central Banks have Precautionary Demands for Expansions and for Price Stability? - Theory and Evidence, August 2002

765 Giovanni Peri, Knowledge Flows and Knowledge Externalities, August 2002

766 Daniel Friedman and Nirvikar Singh, Equilibrium Vengeance, August 2002

767 Sam Bucovetsky and Michael Smart, The Efficiency Consequences of Local Revenue Equalization: Tax Competition and Tax Distortions, August 2002

768 Tapio Palokangas, International Labour Market Regulation and Economic Growth with Creative Destruction, August 2002

769 Rudi Dornbusch, The New International Architecture, September 2002

770 Hans-Werner Sinn, Weber's Law and the Biological Evolution of Risk Preferences: The Selective Dominance of the Logarithmic Utility Function, September 2002

771 Thomas Mayer, The Macroeconomic Loss Function: A Critical Note, September 2002

772 Seppo Honkapohja and Kaushik Mitra, Learning Stability in Economies with Heterogenous Agents, September 2002

773 David Laidler, Inflation Targets Versus International Monetary Integration - A Canadian Perspective, September 2002 
774 Morten I. Lau, Panu Poutvaara, and Andreas Wagener, The Dynamic Cost of the Draft, September 2002

775 Steven Brakman, Harry Garretsen, and Charles van Marrewijk, Locational Competition and Agglomeration: The Role of Government Spending, September 2002

776 Anke S. Kessler and Christoph Lülfesmann, The Theory of Human Capital Revisited: On the Interaction of General and Specific Investments, September 2002

777 Kjell Erik Lommerud, Frode Meland and Lars Sørgard, Unionized Oligopoly, Trade Liberalization and Location Choice, September 2002

778 Antonio Merlo and François Ortalo-Magné, Bargaining over Residential Real Estate: Evidence from England, September 2002

$779 \mathrm{Yu}-\mathrm{Fu}$ Chen and Michael Funke, Exchange Rate Uncertainty and Labour Market Adjustment under Fixed and Flexible Exchange Rates, September 2002

780 Michael S. Michael, International Migration, Income Taxes and Transfers: A Welfare Analysis, September 2002

781 Clemens Fuest and Alfons Weichenrieder, Tax Competition and Profit Shifting: On the Relationship between Personal and Corporate Tax Rates, October 2002

782 Jan Bouckaert and Hans Degryse, Softening Competition by Enhancing Entry: An Example from the Banking Industry, October 2002

783 Johann K. Brunner and Susanne Pech, Adverse Selection in the Annuity Market with Sequential and Simultaneous Insurance Demand, October 2002

784 Gregory D. Hess and Eduard Pelz, The Economic Welfare Cost of Conflict: An Empirical Assessment, October 2002

785 Jan Erik Askildsen, Uwe Jirjahn, and Stephen C. Smith, Works Councils and Environmental Investment: Theory and Evidence from German Panel Data, October 2002

786 Geir H. Bjønnes, Dagfinn Rime, and Haakon O. Aa. Solheim, Volume and Volatility in the FX-Market: Does it matter who you are?, October 2002

787 John Evans and John Fingleton, Entry Regulation and the Influence of an Incumbent Special Interest Group, October 2002

788 Wolfgang Ochel, International Comparisons and Transfer of Labour Market Institutions, October 2002

789 B. Gabriela Mundaca, Moral Hazard Effects of Bailing out under Asymmetric Information, October 2002

790 Gene M. Grossman and Edwin L.-C. Lai, International Protection of Intellectual Property, October 2002 
791 John Hassler, José V. Rodriguez Mora, Kjetil Storesletten, and Fabrizio Zilibotti, A Positive Theory of Geographic Mobility and Social Insurance, October 2002

792 Paul De Grauwe and Marianna Grimaldi, The Exchange Rate in a Model with Heterogeneous Agents and Transactions Costs, October 2002

793 Guido Friebel and Mariassunta Giannetti, Fighting for Talent: Risk-shifting, Corporate Volatility, and Organizational Change, October 2002

794 Jan Erik Askildsen, Badi H. Baltagi, and Tor Helge Holmås, Will Increased Wages Reduce Shortage of Nurses? A Panel Data Analysis of Nurses' Labour Supply, October 2002

795 Marko Köthenbürger and Panu Poutvaara, Social Security Reform and Intergenerational Trade: Is there Scope for a Pareto-Improvement?, October 2002

796 Paul De Grauwe and Laura Rinaldi, A Model of the Card Payment System and the Interchange Fee, October 2002

797 Volker Böhm and Tomoo Kikuchi, Dynamics of Endogenous Business Cycles and Exchange Rate Volatility, October 2002

798 Mariam Camarero, Javier Ordóñez, and Cecilio Tamarit, The Euro-Dollar Exchange Rate: Is it Fundamental?, October 2002

799 Misa Tanaka, How Do Bank Capital and Capital Adequacy Regulation Affect the Monetary Transmission Mechanism?, October 2002

800 Jörg Baten and Andrea Wagner, Autarchy, Market Disintegration, and Health: The Mortality and Nutritional Crisis in Nazi Germany, 1933-1937, October 2002

801 Saku Aura, Uncommitted Couples: Some Efficiency and Policy Implications of Marital Bargaining, October 2002

802 Wolfram F. Richter, Delaying Integration of Immigrant Labor for the Purpose of Taxation, October 2002

803 Gil S. Epstein and Shmuel Nitzan, The Politics of Randomness, October 2002

804 John Hassler and José V. Rodriguez Mora, Should UI Benefits Really Fall over Time?, October 2002

805 Friedrich Breyer and Stefan Felder, The Dead-anyway Effect Revis(it)ed, October 2002

806 Assar Lindbeck and Solveig Wikström, E-exchange and the Boundary between Households and Organizations, November 2002 